
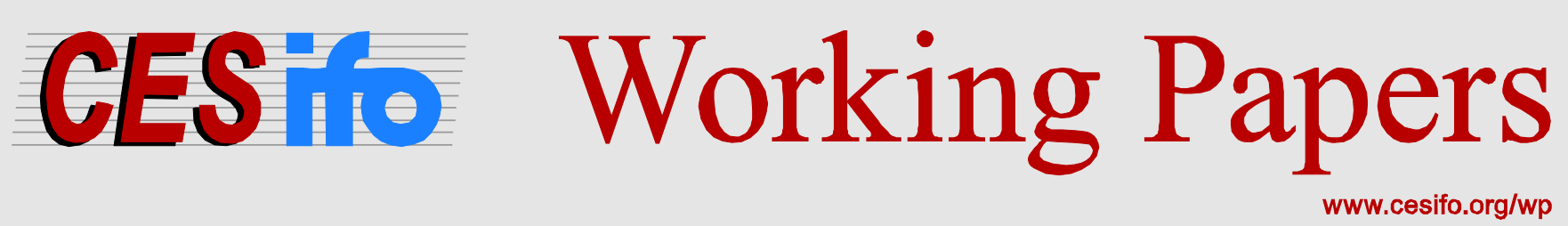

\title{
Are Ex Ante and Ex Post Licensing Agreements Useful Instruments to Lessen Uncertainty in $\mathrm{R} \& \mathrm{D}$ ?
}

\author{
Ralph Siebert
}

CESIFO WORKING PAPER NO. 4535

CATEGORY 11: INDUSTRIAL ORGANISATION

DECEMBER 2013

An electronic version of the paper may be downloaded

- from the SSRN website:

- from the RePEc website:

- from the CESifo website:

WWw.SSRN.com

www.RePEc.org

www.CESifo-group.org/wp

\section{CESifo}




\title{
Are Ex Ante and Ex Post Licensing Agreements Useful Instruments to Lessen Uncertainty in $\mathrm{R} \& \mathrm{D}$ ?
}

\begin{abstract}
In the last decades, technologies became more complex which increased the degree of uncertainty in $R \& D$. To overcome the uncertainty, firms frequently engage in $R \& D$ collaborations, e.g., Research Joint Ventures (RJVs), and licensing agreements. While RJVs are well explored in the literature, very little is known about the use of licensing agreements. Building on a novel database which includes licensing agreements in the semiconductor industry between 1989 and 1999, we estimate a bivariate probit model with self-selection. Our estimation results highlight the fact that firms' relatedness in technology and product markets determine their choices to engage in ex ante and ex post licensing agreements. Our study provides evidence that the decision to engage in ex ante and ex post licensing is formulated with regard to uncertainty in R\&D. While ex ante licensing agreements serve as a useful mechanism to insure against uncertainty in R\&D, ex post licensing agreements rather serve as an instrument to resolve uncertainty in R\&D. Hence, licensing agreements are appropriate instruments to lessen R\&D uncertainty.
\end{abstract}

JEL-Code: L130, L490, L630.

Keywords: innovation, licensing, research joint ventures, $R \& D$ cooperations, $R \& D$ uncertainty, semiconductors.

\author{
Ralph Siebert \\ Purdue University \\ Department of Economics \\ Krannert School of Management \\ 403 West State Street \\ USA - West Lafayette, IN 47907-2056 \\ rsiebert@purdue.edu
}

November, 2013

We would like to thank Jason Abrevaya, Bronwyn Hall, Jeremiah Harris, Georg von Graevenitz, Dietmar Harhoff, Marc Schankerman, Dan Spulber, Theresa Helena Veer and Rosemarie Ziedonis for valuable comments. We are grateful to audiences at Fifth Annual Searle Conferencee on Innovation and Entrepreneurship and several other conferences. The usual disclaimer applies. 


\section{Introduction}

It is widely established that technological progress is an important driver for productivity and growth causing firms to invest large amounts of money into Research and Development (R\&D). In the last decades, technologies became more complex, which increased the degree of uncertainty in R\&D. ${ }^{1}$ Uncertainty in $R \& D$ raises serious concerns for firms and policy makers about the proper functioning of innovation policies. ${ }^{2}$

Firms frequently engage in Research Joint Ventures (RJVs) to lessen uncertainty in R\&D. ${ }^{3}$ RJVs are well explored in the economics and management literature and policy authorities recognize the beneficial impacts of RJVs on total welfare. A RJV is an established instrument among firms to exploit synergy effects, share $R \& D$ costs, lessen $R \& D$ uncertainty, and to overcome free rider effects, among other reasons. ${ }^{4}$

Licensing is a further prominent type of $\mathrm{R} \& \mathrm{D}$ cooperation. Licensing agreements are frequently distinguished between ex ante and ex post licensing agreements, see Tirole (1988); Anand and Khanna (2000); and Spulber (2012). In an ex ante licensing agreement, a firm commits at the beginning of the innovation process to grant patent rights to another firm before the invention is completed. ${ }^{5}$ One example for an ex ante licensing agreement is the following: In January of 1989, Texas Instruments, Inc. and Hitachi Ltd. agreed to share technologies for producing $16 \mathrm{MB}$ Dynamic Random Access Memory chips over the next 3 years. The two companies agreed to share all new data relevant to the next generation chips. Texas Instruments and Hitachi cited high costs and risks associated with developing such chips as reasons for joining forces. Another example is the licensing agreement between Quantum Corp. and Fujitsu Ltd. signed in October of 1999 to develop new products utilizing modern disk drive technology. ${ }^{6}$

In an ex post licensing agreement, a firm grants another firm the right to use its patent after the

\footnotetext{
${ }^{1}$ Complex technologies are frequently associated to high tech industries, such as the semiconductor, information, electronics, and the biotechnology industry as well as medical areas such as genetic diagnostic testing.

${ }^{2}$ For further information, see e.g., Shapiro (2001); Grindley and Teece (1997); Hall and Ziedonis (2001); Clark and Konrad (2008); Gans et al. (2008); Lerner (1995); Galasso and Schankerman (2010).

${ }^{3}$ A Research Joint Venture is an (equity) type of cooperation in which firms jointly perform Research and Development activities.

${ }^{4}$ For possible anticompetitive effects, see e.g., Duso et al. (2013) and Roeller et al. (2007) and Goeree and Helland (2012).

${ }^{5}$ See also Scotchmer (2005); Green and Scotchmer (1995); and Shapiro (1982).

${ }^{6}$ Source: Thomson Financial.
} 
invention has been completed. An example for an ex post licensing agreement is the following: In March of 1991, Advanced Micro Devices (AMD) and Atmel Corp. have signed a licensing agreement under which Atmel granted AMD a license to its patent portfolio, including those for non-volatile memory technology. In return, AMD granted Atmel a license for its own patent portfolio, excluding AMD's new programmable logic devices. ${ }^{7}$

Even though both types of licensing are widely applied among firms, very little is known about the determinant and objectives to engage in these different types of licensing agreements, see Merges and Nelson (1990); Merges (2001); Epstein et al. (2012). To date, few empirical studies focus on licensing, while most studies concentrate on ex post licensing agreements, see e.g., Scotchmer (2005); Galasso (2012); Arora and Fosfuri (2003); Arora and Ceccagnoli (2006); and Anand and Khanna (2000). Our study focuses on two questions: 1) Are licensing agreements appropriate instruments for firms to lessen uncertainty in R\&D? 2) Which factors determine firms' choices between ex ante or ex post licensing agreements?

Our study highlights the fact that firms' relatedness in technology and product markets determine their choices to select themselves into ex ante and ex post licensing agreements. Regarding firms' relatedness in technology markets, we stress that more complex technologies increase the likelihood that other firms hold some of the required patents which are necessary to invent a new technology. If some of the required patents are held by competitors, firms are not able to complete an inventions, in which case the invention of a new technology is blocked. The risk of facing blocking patents held by competitors, describes an uncertainty in $R \& D$ as innovators are hampered from successfully inventing a new technology. Uncertainty in R\&D can also be caused by an overlap in patent rights. Patent overlap arises from a variety of reasons, such as the validity and scope of patents, the strength and enforceability of patent claims, firms' ability to invent around other firms' inventions, and the difficulty of patent offices to reject weak patents, see also Heller and Eisenberg (1998); Shapiro (2001); Federal Trade Commission (2003); Lei and Wright (2009); Galasso et al. (2013). Moreover, more closely related firms in technological markets are able to benefit from higher technological spillovers or synergy effects. ${ }^{8}$

\footnotetext{
${ }^{7}$ Source: Thomson Financial. The next section provides more information and descriptive statistics on both types of licensing.

${ }^{8}$ Previous work on R\&D collaborations shows that firms increase profits after forming R\&D collaborations if technological spillovers are high as it allows firms to to exploit synergy effects, as well as to overcome free rider effects, see e.g, D’Aspremont and Jacquemin (1988); Katz (1986); Kamien et al. (1992).
} 
Beyond firms' relatedness in technology markets, we also account for firms' relatedness in product markets having an impact on licensing decisions. Earlier work on R\&D collaborations has shown that firms' relatedness in product markets plays an important role in firms' decisions to cooperate. Kamien et al. (1992), for example, show that R\&D cooperations result in higher profits, if (for any given level of synergy effects in technology) products are less differentiated in the product market or competition is higher. ${ }^{9}$ Moreover, firms with larger production facilities receive higher value added from forming $R \& D$ cooperations, as innovations can be incorporated into a larger production scale. Finally, $R \& D$ cooperations incorporate the risk that they can be used as an predatory instrument by larger firms to drive smaller firms out of the market, see Roeller et al. (2007).

Up to date, very little is known if the relatedness in technology and product markets also determine firms' incentives to engage in different types of licensing agreements, and which types of licensing agreements represent more useful instruments to solve R\&D uncertainty. Earlier excellent studies focused on ex post licensing. For example, Katz and Shapiro (1987) study how licensing agreements between duopolists affect the speed of innovation; Gallini (1984) highlights the fact that licensing can be used by an incumbent to deter a potential entrant from performing its own R\&D; Gallini and Winter (1985) show that incumbents have an incentive to license innovations to competitors so as to weaken rivals' future R\&D incentives. For studies investigating the private and social incentives to engage in ex post licensing agreements, see also Nordhaus (1969); Galasso (2012); Arora and Fosfuri (2003); Arora and Ceccagnoli (2006). Finally, a large number of studies related to ex ante and ex post licensing agreements focus on patent pools and research joint ventures, see e.g., Greenlee (2005); Lampe and Moser (2010); Lampe and Moser (2012); Lerner and Tirole (2004); Jeitschko and Zhang (2013); Gallini (2011); Gilbert and Katz (2011) and the references cited therein.

We use a novel and comprehensive database which contains highly disaggregate data, i.e., firmlevel licensing, production and patent data in the semiconductor industry between 1989 and 1999. The data allow us to thoroughly study firms' licensing choices, dependent on their relatedness in the semiconductor technology and product markets. We employ a bivariate probit model with self-

\footnotetext{
${ }^{9}$ In a similar vein, Branstetter and Sakakibara (2002); Bloom et al. (2013) highlight the relevance of the relationship between technological and product market competition when determining firm value and innovation activity.
} 
selection, in which firms first decide between ex ante licensing and no licensing. That decision is made before any inventions have been realized. After inventions are realized, the firms who decided not to engage in an ex ante licensing agreement have the opportunity to form an ex post licensing, or not.

Our results show that licensing is an important instrument for firms who operate in complex technology markets characterized by high uncertainties in R\&D. We show that ex ante and ex post licensing agreements serve specific functions and purposes for firms to operate in uncertain environments. An ex ante licensing agreement is used by firms as an instrument to avoid blocking each others' inventions. More specifically, firms make use of ex ante licensing if the probability of other firms holding a blocking patent (after inventions are realized) is high. If the probability of discovering blocking patents is low, firms do not engage in ex ante licensing as it offers the possibility not to engage in licensing at all, which saves on transaction costs related to establishing licensing agreements. If firms, initially decided not to form an ex ante licensing agreement as the expected degree of blocking was only low, they engage in ex post licensing after inventions realized and the realized blocking turned out to be high. Ex post licensing agreements allow firms to resolve high degrees of realized blocking caused by $R \& D$ uncertainties.

Our estimation results also return remarkable findings with respect to firms' relatedness in technology and product markets. While technological relatedness between firms in technology markets (i.,e., blocking) are strong predictors for firms' licensing choices, patent count measures (i.e., the size of firms' patent stocks) are less powerful in explaining firms' licensing choices. Our results also confirm more widely distributed ownership rights constitute an impediment to engage in licensing deals as negotiation about ownership rights becomes more complex. The estimation results also show that transaction costs are an important characteristic, as profound organizational and legal expertise are required to negotiate rights with potential competitors. In regard to firms'activeness in product markets, both types of licensing are important for firms with large and more similarly sized production facilities. We performed several robustness checks for testing exclusion restrictions, alternative blocking variable definitions and model specifications. To summarize, our study highlights the fact that ex ante and ex post licensing agreements serve as an appropriate instrument to insure and secure firms against uncertainty in R\&D, and guarantee "freedom to operate" (Grindley and Teece, 1997; Clark and Konrad, 2008). 
The remainder of the paper is organized as follows: in Section 2 we introduce the data sources and describe licensing trends in the semiconductor industry. Section 3 introduces the variable definitions and provides descriptive statistics. In Section 4, we introduce the empirical model and discuss the results and robustness checks. Finally, Section 5 concludes.

\section{Licensing in the Semiconductor Industry}

Semiconductors are mainly used as inputs for the computer industry, consumer electronics, and communications equipment. The semiconductor market consists of memory chips, micro components, and other components such as logic devices. The semiconductor industry is one of the key industries influencing economic growth and characterized by a high innovative activity, see also Hall and Ziedonis (2001). Licensing is an important instrument for semiconductor firms to keep up with the high pace of innovation. Anand and Khanna (2000) remark that the level of licensing in the semiconductor industry is high, relative to other industries. This supports the semiconductor industry as a natural object to focus on.

Our study is based on a novel dataset on licensing agreements signed between semiconductor firms from 1989 until 1999. The basis of our data on licensing contracts was provided by Thomson Financial. We complemented the data with information derived from sources in the public domain such as business reports, filings published in the National Cooperative Research Act, and announcements made in the public press. We identified name changes, subsidiaries and mergers from a variety of sources including Thomson Financial, Gartner, and Moody's. Our licensing dataset encompasses information on the date when the licensing contract was signed, the participating firms and a synopsis indicating the type of licensing, i.e., whether firms signed ex ante or ex post licensing contracts. The dataset includes 847 licensing contracts between 268 semiconductor firms. ${ }^{10}$ On average, a firm engaged in 6 contracts during the time span. The vast majority of contracts in this sample is bilateral.

We concentrate in our empirical analysis on horizontal licensing agreements, as we have detailed firm-level data on the semiconductor industry. Even though a focus on vertical licensing

\footnotetext{
${ }^{10}$ Note, firms entered and exited the industry throughout the time period. In total, 268 firms ever participated in the semiconductor industry in the entire period. At a specific point of time, however, around 150 firms were active in the market
} 
agreements would be very interesting, it would go beyond the scope of this paper. It should be noted that the concentration on horizontal licensing agreements still leaves us with a sufficiently large number of licensing contracts (847) performed in the semiconductor industry. Note also, the licensing agreements do not contain information on specific patents or technologies. Hence, our study is performed at the most possible disaggregate level. Finally, we would like to emphasize the fact that we have no information on licensors and licensees, licensing fees, and specific technologies or patents that were contracted. Consequently, our study rather concentrates on the determinants of different types of licensing taking advantage of the highly disaggregate firm level information in the semiconductor product and technology markets.

Figure 1a displays the number of licensing agreements over time relative to 1989. It is interesting to note that the number of licensing contracts follows an inverse U-shape over time, i.e., the number of licensing agreements sharply increased until 1992 and then drastically decreased after 1995. ${ }^{11}$

To show that the decline decline in the number of licenses at the end of the 90's is not caused by fewer semiconductor firms being active in the market during that time period, we weight the total number of licensing agreements by the number of active semiconductor firms. Figure $1 \mathrm{~b}$ shows that the inverse U-shape still applies and dismisses the conjecture that the inverse U-shape is accompanied by a change in the number of firms in the market.

Next, we deepen our insights on the different types of licensing and distinguish between ex ante and ex post licensing. As mentioned above, firms commit in ex ante licensing contracts to provide a certain technology (or patents) to other firms before the technology has been explored. Ex post contracts cover cases in which firms grant rights to other firms for already existing technologies (or patents). ${ }^{12}$ We categorized contracts into 549 ex ante licensing contracts and 298 ex post licensing contracts. Note, more than $98 \%$ of the contracts were unambiguously classified into ex ante or ex post licensing contracts. In only $2 \%$ of the cases licensing contracts were categorized into both, ex ante and ex post licensing deals. Remarkably, our data show that ex ante licensing contracts are more frequently performed than ex post licensing. Figure 1c shows the evolution of ex ante and ex post licensing agreements over time. It is interesting to note that the inverse U-shape we

\footnotetext{
${ }^{11}$ Thomson Financial confirmed to us that the observed patterns are not due to changes in data collection methods. They also confirmed that the licensing contracts represent a close to complete sample.

${ }^{12}$ Note, that ex ante licensing agreements are only very rarely used for outsourcing innovation activities.
} 
observe in Figure 1a is mostly explained by the evolution of ex ante licensing agreements over time. The number of ex post licensing agreements remained relatively stable throughout the entire time period. In the next section, we further describe how the number of licensing agreements evolve with blocking.

We also use detailed firm-level information on the semiconductor product and technology markets in order to explain firms' licensing decisions. Based on a dataset provided by Gartner, Inc., we can track firms' market shares in the semiconductor industry from 1989 until 1999. ${ }^{13}$ The database covers approximately 270 international semiconductor firms. Figure $1 \mathrm{~d}$ shows that total revenues in the semiconductor industry grew substantially throughout the entire period. This trend is accompanied with a modest increase in the number of active semiconductor firms.

In order to establish firms' activeness in the semiconductor technology market, we identified firms' patents at the firm-level related to semiconductors. We include all inventions that have been applied for and subsequently granted in the U.S. The patent data themselves were procured from the U.S. Patent and Trademark Office. We use U.S. patents because the U.S. is the world's largest technology marketplace and it has become routine also for non-U.S. based firms to patent in the U.S. (see Albert et al., 1991). The patent data are provided by the NBER patent database established by Hall et al. (2001). ${ }^{14}$ Figure 1a displays the evolution of granted patents relative to 1989. The number of new patents granted to semiconductor firms more than doubled over the period of our sample. Surprisingly, even though the number of patents drastically increased, the licensing trend follows an inverse U-shape. We would expect licensing to become a more attractive alternative as the number of patents grows. This fact indicates that patent counts might not fully capture firms' licensing decisions. We return to this point in the next section.

Table 1 provides further descriptive statistics on ex ante and ex post licensing agreements. A firm which engaged in ex ante (ex post) licensing was granted 128 (137) patents and its patent stocks attracted a total of $1,056(1,145)$ citations over the sample period. Further descriptive statistics are mentioned in the next section, where we introduce our variables.

\footnotetext{
${ }^{13}$ See the Appendix for further details on the semiconductor production database.

${ }^{14}$ See the Appendix for further information on the patent database.
} 


\section{Variable Definitions and Descriptive Statistics}

Next, we introduce firms' decision making process of engaging in ex ante and ex post licensing agreements. We also present our variable definitions.

Firms choose to engage in ex ante or ex post licensing agreements, or not to do licensing at all based on the value they derive from those alternatives. Before investing into the discovery of new technologies, firms have the choice to form an ex ante licensing agreement and jointly perform R\&D, or not to form a licensing agreement. Firms decide to form ex ante licensing agreements before innovations are realized. Hence, their ex ante licensing decision will be based on the expected degree of blocking, i.e., what they believe the realized degree of blocking will be in the future (after inventions have been realized). Hence, their ex ante licensing decision is made depending on their expectation about the realized degree of blocking in the future, beyond other controls which reflect firms' activeness in the technology and product markets. After innovations have been realized, those firms who did not form an ex ante licensing agreement have the option to form an ex post licensing agreement or not to license. This decision is made based on the realized degree of blocking as well as other control variables. The sequence of firms' decision making process is illustrated in Figure 2.

Before we turn to the empirical model, we introduce the variable definitions.

Realized Blocking - $B_{i j t}$ We are interested in explaining how realized blocking impacts firms' licensing decisions. We establish a blocking measure which is based on firms' closeness and relatedness in technology space. More closely related technologies between firms increase the likelihood that a patent is held by a different firm, i.e., a blocking patent. Hence, the density in the technological space and the likelihood of facing blocking patents increases which causes uncertainty in R\&D, see Levin et al. (1987); Teece (1986); Shapiro (2001). If firms patent in similar technology classes and frequently cite each others' patents, they are related in technology space and the likelihood of blocking each other is high. The blocking measure is formulated based on firm-pairs and consists of two parts: Firms' technological proximity $\left(S_{i j t}\right)$ between firms $i$ and $j$ in period $t$, and their cross citations, i.e., the extent to which they cite each other $\left(C_{i j t}\right){ }^{15}$

The technological similarity $\left(S_{i j t}\right)$ is based on the uncentered correlation coefficient see, e.g.,

\footnotetext{
${ }^{15}$ Similar measures are applied in the literature on innovation to capture technological proximity, see e.g., Jaffe (1986); Bloom et al. (2013); Noel and Schankerman (2013).
} 
Jaffe (1986), which measures the relationships between firms' patents across nine patent classes, to which all semiconductor patents are assigned by the United States Patent and Trademark Office. ${ }^{16}$

The formal definition of this measure is as follows:

$$
S_{i j t}=\frac{\sum_{c=1}^{9} A_{i c t} A_{j c t}}{\sqrt{\sum_{c=1}^{9} A_{i c t}} \sqrt{\sum_{c=1}^{9} A_{j c t}}}
$$

where $A_{l c t}$ is the number of patent applications by firm $l \in\{i, j\}$ in patent class $c$ and period $t$.

The citation intensity $\left(C_{i j t}\right)$ is measured using the number of cross citations between firm $i$ and firm $j$, divided by the total number of firm $i$ 's citations:

$$
C_{i j t}=\frac{c_{i j t}}{\sum_{k} c_{i k t}}
$$

where $c_{i j t}$ is the number of citations of firm $j$ by firm $i$, and $c_{i k t}$ is the number of citations of firm $k$ by firm $i$, and $k \in K$ is the total number of $K$ firms present in the industry.

Hence, blocking is defined as:

$$
B_{i j t}=\left(C_{i j t}+C_{j i t}\right) S_{i j t}
$$

Note, that blocking is allowed to be asymmetric between firm-pairs. Table 2 below shows descriptive statistics on the blocking measure. Interestingly, Table 2 reports that the measure of realized degree of blocking $(B)$ under ex post licensing (0.011) is higher than under no licensing (0.005). Figure 3a shows that blocking initially increased and then decreased over the sample period. The evolution of the blocking variable replicates the licensing trend remarkably well.

We test and confirm the appropriateness of our definition of blocking using additional information on patent claims using European patents. Every European patent provides information on any previous patents which reduce the scope of protection for the patent under consideration. References to these patents are called $X$ and $Y$ references and they are determined by the patent examiner, which increases the objectivity of the information. This information is also used by von Graevenitz, Wagner and Harhoff (2011). Using this data, we generate a count on the number of

\footnotetext{
${ }^{16}$ The patent classes are identified by Hall et al. (2005) as the classes 257, 326, 438, 505 (semiconductors), $360,365,369,711$ (memory) and 714 (microcomponents).
} 
blocking patents for each firm pair and construct alternative measures of blocking. We consider contemporaneous counts as well as the stock of patents with $X$ and $Y$ references and a discounted stock of these patents. Next, we identify the equivalent European semiconductor patents for the U.S. semiconductor patents in our data set and examine the correlation between our blocking measure and the blocking just described. ${ }^{17}$ The correlation is always in the medium range $(>0.3)$ and significantly different from zero. Appendix D also provides the estimation results of our main empirical model using the alternative measures of blocking as a robustness check.

Expected Blocking - $E B_{i j t}$ Firms make their decision to engage in ex ante licensing before investing in $R \& D$ and before inventions are realized, see Figure 2. Firms' decision to engage in ex ante licensing or not is based on the expectation (formed at period $t$ ) of what realized blocking turns out to be after inventions are completed in period $t+1$. We assume that firms are characterized by perfect foresight, and measure the expected degree of blocking in period t using the realized degree of realized blocking in period $\mathrm{t}+1$. Table 2 shows that the expected degree of blocking $(E B)$ is twice as high for firms which formed ex ante licensing agreements (0.007) than firms which did no licensing (0.004).

We use further variables to control for firms' activeness in the technology markets:

Average Semiconductor Patent Stocks - $A S P S_{i j t}$ The size of firms' joint patent stocks is an indicator for firms' innovative activity and intellectual knowledge within a firm. Table 2 shows that licensing firms have larger patent stocks than no-licensing firms.

Difference in Semiconductor Patent Stocks - $D S P S_{i j t}$ This variable measures differences in firms' activity in technology markets and allows us to control for predatory arguments, e.g., less innovative firms are excluded from forming licensing agreements. Table 2 shows that the difference in patent stocks is largest for licensing firms.

Fragmentation - $F_{i j t}$ We establish a variable that controls to what extent ownership of intellectual property rights are fragmented or concentrated between firms. If the ownership of patents needed by one firm to successfully invent a new technology are highly fragmented across firms, many licensing agreements have to be formed, which lowers the likelihood of successfully acquir-

\footnotetext{
${ }^{17}$ To identify the equivalent patents we use a data set provided by Dietmar Harhoff.
} 
ing all necessary patents. ${ }^{18}$ We follow earlier literature and construct a fragmentation variable, which measures the fragmentation of firms' patent citation stocks at the period when they make their licensing decision. ${ }^{19}$ Figure $3 \mathrm{~b}$ presents the evolution of fragmentation of technology ownership over time.

Finally, we control for firms' activeness in the product markets:

Average Semiconductor Market Shares - $A S M S_{i j t} \quad$ Firms characterized by large production facilities are able to apply their inventions on a larger scale and experience higher gains from successful innovation. Hence, larger firms have higher incentives to using licensing as a device to acquire remaining parts of an innovation. Moreover, Stuart (1998) shows that firms with more prestige in the semiconductor industry are more likely to form alliances. ${ }^{20}$ His measure of prestige is highly correlated with firm size. Hence, we use the average market share of each firm pair in the semiconductor product market. Table 2 shows that firm pairs that engage in licensing have larger market shares on average than firm pairs that do not engage in licensing.

Difference in Semiconductor Market Shares - $D S M S_{i j t}$ This variable measures firm size asymmetries for each firm pair in the semiconductor industry. Descriptive statistics in Table 2 show the difference in market shares is lowest for firm-pairs which engaged in ex post licensing.

Multimarket Participation in Semiconductors - $M M K T_{i j t} \quad$ Firms operating in multiple submarkets within the semiconductor industry are able to benefit from higher synergy effects if the corresponding technologies are closely related. We separate the semiconductor industry into 3 different submarkets: microcomponents, memory chips and other devices. Using firm-level information we establish a counter that refers to the number of submarkets a firm operates in.

Transaction Costs for Ex ante and Ex post Licensing $E x p E A L_{i j t}, E x p E P L_{i j t}$

The engagement in licensing agreements involves high initial transaction costs as profound organizational and legal expertise are required to negotiate rights with potential competitors. Firms also have to devote time and resources in designing licensing contracts. Firms which collected more

\footnotetext{
${ }^{18}$ Ziedonis (2004) shows that fragmentation explains some of the large increase in patenting levels in the semiconductor industry.

${ }^{19}$ We also apply the correction suggested in the appendix of Hall et al. (2005) to control for a bias resulting from low counts.

${ }^{20}$ His definition of alliances subsumes licensing agreements as well as other forms of cooperation.
} 
experience in licensing face lower transaction costs for subsequent contracts. We control for experience in ex ante and ex post licensing separately as these types of contracts are usually designed differently. The variables ExpEAL $L_{i j t}$ and $\operatorname{ExpEP} L_{i j t}$ count the sum of the ex ante and ex post licensing agreements performed by firm $\mathrm{i}$ as well as firm $\mathrm{j}$.

Descriptive information for all variables used in our empirical model are shown in Table 2. We now turn to introducing the empirical model.

\section{Firms' Licensing Choices: The Bivariate Probit Selection Model}

In this section, we introduce the empirical model specification to explore the determinants of ex ante and post licensing agreements.

We consider a sequential self-selection model, as illustrated in Figure 2, since the decision to ex post licensing is defined only over the subset of firms that did not engage in ex ante licensing, see e.g., Maddala (1986), and Wooldridge (2002). Hence, the likelihood to engage in ex post licensing is conditioned on the decision not to form ex ante licensing.

Firms choose at the first stage whether to form an ex ante licensing agreement, or not. $V_{i t}^{a}$ is the value a firm $i$ receives from forming an ex ante licensing agreement in period $t$. Those firms who decide not to engage in ex ante licensing agreements, then decide whether to engage in ex post licensing, or not, see Figure 2. If they engage in ex post licensing, they receive a value $V_{i t}^{p}$. The firm value from not forming a licensing agreement is denoted by $V_{i t}^{n}$.

We apply a bivariate probit model with self-selection, Heckman (1979), where the first probit equation describes firms' decision to engage in ex ante licensing, or no licensing. We do not observe firms' value, but we observe firms choices to engage in ex ante, ex post or no licensing. We observe ex ante licensing, if $E A L_{i, t}^{*}=V_{i t}^{a}-V_{i t}^{n}>0$, where $E A L_{i, t}^{*}$ is the latent variable measuring the underlying propensity to do ex ante licensing. In this case, the ex ante licensing dummy variable $E A L$ takes on a value of one, otherwise it is zero. The decision to form an ex ante licensing agreement is specified as follows: 


$$
\begin{aligned}
& E A L_{i j t}^{*}=\alpha_{0}+\alpha_{1} E B_{i j t}+\alpha_{2} A S P S_{i j t}+\alpha_{3} D S P S_{i j t}+\alpha_{4} F_{i j t}+\alpha_{5} A S M S_{i j t}+\alpha_{6} D S M S_{i j t} \\
& +\alpha_{7} M M K T_{i j t}+\alpha_{8} \operatorname{Exp} E A L_{i j t}+\sum_{t=1}^{8} \gamma_{t} D_{i j t}+\epsilon_{i j t}^{a} .
\end{aligned}
$$

Note, the decision to form an ex ante licensing agreement depends on the expected degree of blocking $(E B)$. We include further control variables that refer to firms' relatedness and positions in technology and product markets as introduced above, as well as year dummies denoted by $D_{i j t}$. The error term $\left(\epsilon^{a}\right)$ is assumed to be normally distributed.

The second probit describes firms' decision to form ex post licensing or no licensing. Note that this probit is censored and only observed if the first probit takes on a value of 0 . The ex post licensing dummy variable $E P L$ takes on a value of one, if the latent variable for ex post licensing $E P L_{i, t}^{*}=V_{i t}^{p}-V_{i t}^{n}>0$, otherwise it is zero. The decision to engage in ex post licensing is specified as:

$$
\begin{aligned}
& E P L_{i j, t}^{*}=\beta_{0}+\beta_{1} B_{i j, t}+\beta_{2} A S P S_{i j, t}+\beta_{3} D S P S_{i j, t}+\beta_{4} F_{i j, t}+\beta_{5} A S M S_{i j, t}+\beta_{6} D S M S_{i j, t} \\
& +\beta_{7} M M K T_{i j, t}+\beta_{8} \operatorname{ExpEP} L_{i j, t}+\sum_{t=1}^{8} \delta_{t} D_{i j t}+\epsilon_{i j, t}^{p} .
\end{aligned}
$$

Note, the decision depends on the realized degree of blocking $(B)$. The error term $\left(\epsilon^{p}\right)$ is assumed to be normally distributed.

In estimating this model we have to be aware of the fact that self-selection issues arise, as more productive firms in technology and product markets expect a higher return from engaging in licensing. Moreover, firms also expect a return from licensing due to some unmeasured variables such as managerial ability. Hence, firms form licensing agreements not only based on their expected value associated to technology or product market positions, but also dependent on the error terms. As a consequence, the error terms are potentially correlated between both equations which causes a selection problem due to an omitted variable bias.

For identifying the bivariate probit model with self-selection, we need an exclusion restriction, 
i.e., a variable which affects the decision to engage in ex ante licensing but does not impact the decision to form ex post licensing. In our case the decision to engage in ex ante licensing depends on the expected degree of blocking, while the decision to engage in ex post licensing is independent on expected blocking, but depends on the realized degree of blocking. More specifically, if blocking is expected to be high, firms engage in ex ante licensing to avoid the risk of facing blocking patents and potential litigation cases. If the expectation of facing blocking patents is sufficiently low, firms will prefer not to engage in ex ante licensing as it offers the possibility not to engage in licensing at all, which saves on transaction costs.

After the innovations are realized, firms make their ex post licensing decision depending on the realized degree of blocking. If realized blocking turns out to be low, firms will not have to license at all. In case, the realized blocking is high, firms will engage in ex post licensing. Further below, we perform several robustness checks and test the exclusion restriction.

A further exclusion argument builds on the transaction cost literature which argues that ex ante and ex post licensing are beset with organizational challenges, high contracting costs, and managerial expertise. More experience in forming ex ante and ex post licensing lowers those transaction costs and increases the likelihood to engage in further ex ante and ex post licensing agreements. Since the transaction costs and experience is specific to the type of licensing, we distinguish between experience in ex ante and ex post licensing. Therefore, the experience in ex ante licensing only enters the first probit and is excluded from the ex post licensing probit.

The results and several robustness checks are reported in the next section.

\subsection{Estimation Results}

We estimate equations (2) and (3) using a seemingly unrelated version of the bivariate probit model, since we have different independent variables in the probits and allow for correlation between errors. Based on a sample of 30,905 observations, we estimate the model using Maximum Likelihood.

The results are shown in Table 3 with corrected standard errors reported in parentheses. The estimate of the selection term $\rho$ is 0.53 and significant, indicating a positive correlation between residuals in both probit equations. The significant correlation coefficient also provides evidence that the decision of engaging in ex post licensing agreements is not independent on the decision 
to engage in ex ante licensing. A positive correlation seems plausible as shocks that lead firms to avoid ex ante licensing, will raise the likelihood to license ex post given they face a high degree of realized blocking. Moreover, the correlation parameter confirms the relevance to apply a bivariate probit model opposed to estimating both probit models independently. We also applied a robustness check and estimated both probit equations separately. The likelihood ratio test and Wald test statistics confirm that $\rho$ is significantly different from zero, and the bivariate probit provides a better model fit.

The estimates of the ex ante licensing decision as per equation (2) are shown in Table 3, Column (1). The results show that a higher degree of expected blocking significantly increases the probability of ex ante licensing. How important are the blocking measures in determining firms' licensing choices? The calculated marginal effect indicates that a $1 \%$ increase in expected blocking increases the likelihood by $6 \%$. Or, a one standard deviation increase in the expectation of blocking raises the probability of observing ex ante licensing by $12 \%$.

As shown in Table 3, Column (2), higher realized blocking increases the likelihood of forming ex post licensing agreements. The probability of observing ex post licensing increases by (30\%) if blocking increases by one standard deviation and the calculated marginal effects indicate that a $1 \%$ increase in blocking increases the likelihood by $20 \%$. Both estimation results confirm the relevance of expected and realized blocking in determining firms' licensing choices. If expected blocking patents is sufficiently low, firms will not engage in ex ante licensing as it offers the possibility not to engage in licensing at all, which saves on transaction costs. If the realized blocking turns out to be high, they engage in ex post licensing.

Next, we thoroughly perform robustness checks on our exclusion restriction as well as the definition of our blocking variable. Remember, expected blocking $(E B)$ enters the ex ante licensing equation (2) as an instrument, assuming it does not impact the decision to form an ex post licensing agreement. To test for the validity of the exclusion restriction, we now include the expected blocking variable in the ex post licensing equation (3). The results are shown in Table 3, Columns (3) and (4). As shown in Column (4), the expected blocking turns out to be insignificant which is a reasonable outcome as ex post licensing is supposed to be dependent on realized blocking but rather independent of expected blocking. This result confirms the decision making process as illustrated in Figure 2 as well as our identification strategy. Moreover, a likelihood ratio test comparing 
the two bivariate probit models confirms that expected blocking is a valid exclusion restriction $\left(\chi^{2}(1)=1.3\right)$. A further argument that emphasizes the validity of our instrument, the standard errors are relatively small in our estimations which emphasizes the fact that multicollinearity is not a concern and we have sufficient variation entering the selection term. As noted above, we also thoroughly tested for the robustness of our blocking measure. We constructed an alternative measure of blocking, which is based on a direct indicator of blocking between patents contained in European patent data. The estimation results are shown in Appendix D, Table 5. The results confirm expected blocking matters for ex ante licensing and realized blocking significantly impacts the decision to form ex post licensing agreements.

Regarding the relevance of firms' activeness in technology markets on the licensing decisions, we find the size and difference in patent portfolios ( $A S P S$ and $D S P S)$ does not have a significant impact on ex ante licensing or ex post licensing. One exception is that ex post licensing becomes more likely between firms with more similar patent stocks.

The fragmentation of patent ownership $(F)$ only matters for ex ante licensing. An increase in fragmentation has a negative significant effect on ex ante licensing. This result highlights that ex ante licensing is a more likely option when ownership in patent rights are more concentrated. In case ownership rights become more fragmented, several licensing contracts had to be signed to adopt a new technology which involves high transaction costs. Since we observe that fragmentation increased by over 0.4 over the sample period, it corresponds to a smaller probability of observing ex ante licensing of $10 \%$. Hence, the trend towards greater fragmentation of patent rights becomes a concern for using ex ante licensing as a successful device to prevent blocking. Interestingly, higher fragmentation does not have a significant impact on ex post licensing, which is a reasonable outcome for the following reason: In contrast to ex ante licensing where firms still have the option to do ex post licensing in case realized blocking turns out to be high, firms have no other choice than forming an ex post licensing agreement if realized blocking is high.

Turning to the estimation results with regard to firms' activeness in the semiconductor product markets $(A S M S$ and $D S M S)$, our results in Table 3 show that ex ante and ex post licensing is more likely among larger and more similar firms. For example, if firms double their market shares, it raises the probability of observing ex ante and ex post licensing by $14 \%$.

Multimarket participation does not turn out to be significant. Hence, different submarkets are 
characterized by rather dissimilar technologies, offering only little overlap in technologies.

Note, that experience in ex ante (ex post) licensing increases the probability of performing ex ante (ex post) licensing. The coefficients are highly significant. A further licensing contract increases the probability of licensing by around $10 \%$.

Finally, we perform a further robustness check and include the technological similarity $\left(S_{i j t}\right)$ as a separate regressor in the bivariate probit model. This allows us to test if technological similarity is the underlying driver for the blocking variable such that firms' licensing decisions are dependent on technological similarity rather than blocking. The estimation results in Table 4 show that technological classes per se do not have significant explanatory power for firms' licensing choices. This result confirms the relevant role of blocking in our model. It also reemphasizes the validity of our blocking variable definition which again turns out to be significant. Note also that we confirm the fact that expected blocking does not significantly enter the ex post licensing decision, see Table 4, Column (4).

\section{Conclusion}

Many industries are characterized by increasingly complex technologies and firms face a higher degree of uncertainty in $R \& D$ when inventing new technologies. To overcome uncertainty in $R \& D$, firms frequently engage in R\&D collaborations such as Research Joint Ventures (RJVs) which are widely explored. Licensing is another popular type of R\&D collaborations, and very little is known about firms' incentives and objectives of selecting themselves into different types of licensing agreements.

Based on a novel dataset on licensing agreements, we distinguish between ex ante and ex post licensing. Our estimation results provide evidence that licensing as an instrument to lessen uncertainty in R\&D and serve as an instrument for firms to guarantee "freedom to operate" (Grindley and Teece, 1997; Clark and Konrad, 2008). Our study concludes that licensing agreements are an important instrument for firms to secure themselves against uncertainty in R\&D. Firms engage in ex ante licensing to prevent blocking. In contrast, ex post licensing agreements are formed between firms to eventually resolve blocking. Our results also show that ex ante licensing becomes a less attractive instrument for firms as patent ownership becomes more fragmented. Importantly, ex post 
licensing appears to be more important for firms with large product market shares and ex ante (ex post) licensing is popular among more similar (dissimilar) firm pairs in technology.

On a final note, the incentives and determinants of engaging in licensing agreements is still an unexplored area and further research is warranted. We do not have information on specific licensing characteristics, such as licensing fees and specific technologies and patents that were part of the contracts. Those aspects are of relevance and interest for future research but beyond the scope of the current paper. 


\section{Appendix}

\section{A Data Sources}

This section provides details about the origin of our data on licensing, production and patents in the semiconductor industry.

\section{A.1 Licensing Data}

Our data on licensing in the semiconductor industry are provided by Thomson Financial and cover the time period 1989 until 1999. We added data from other data sources such as business reports, filings published in the National Cooperative Research Act, and announcements made in the public press.

Our empirical analysis on licensing concentrates on horizontal technology licensing. Hence, we have excluded vertical partnerships between semiconductor firms and computer, microelectronic or multimedia firms. In line with previous literature, we classified a licensing contract as horizontal if more than $50 \%$ of the firms had sales in the semiconductor industry. We also excluded contracts that were based exclusively on production and marketing licenses. Finally, we dropped another 22 licensing contracts which were related to litigation cases. This left us with 847 contracts.

\section{A.2 Production Data}

Annual firm-level semiconductor market data for different market segments (memory chips, microcomponents, and other devices) were provided by Gartner, Inc. We cover approximately the whole population of international semiconductor firms. Hence, we are able to include non-public firms and do not need to rely on business sheet information to infer market shares. On average, there are 268 companies present in the market every year. Approximately $60 \%$ of the firms had their headquarters in the U.S., whereas the rest were located in Japan, Europe, and other Asian countries. Again, we correct for mergers and acquisitions that were announced in the above mentioned sources. We have firm-level market share information. 


\section{A.3 Patent Data}

In order to capture firms' positions in technology space we use information on patents applications which were subsequently granted. By filing a patent, an inventor discloses to the public a novel, useful, and non-obvious invention. If the patent gets granted, the inventor receives the right to exclude others from using that patented invention for a certain time period, which is 20 years in the U.S. We use U.S. domestic patents in our study because the U.S. is the world's largest technology marketplace and it has become routine for non-U.S.-based firms to patent in the U.S. Albert et al. (1991). Our data on granted patents are taken from the NBER patent data set established by Hall et al. (2005). ${ }^{21}$ The database comprises detailed information on 3 million U.S. patents granted between 1963 and 1999, and all citations made between 1975 and 1999 (more than 16 million).

Using the patent database, we extract detailed patent information for every semiconductor firm for our sample period 1989-1999. We use the number of annual patent applications which were subsequently granted, patent stocks (accumulated patents) dating back to 1963, as well as patent citations dating back to 1975. Moreover, in order to establish firms' position in technology space at a disaggregated level, we make use of information about the technology area that the filed invention belongs to. The United States Patent and Trademark Office (USPTO) has developed a highly elaborate classification system for the technologies to which the patented inventions belong consisting of about 400 main 3-digit patent classes. Each patent is assigned to an original classification. Based on the classifications provided by the USPTO and Hall et al. (2005) and we chose those patent classes that represent memory chips, microcomponents and other semiconductor devices.

As the patent database lasts only until 1999, we need to account for truncation issues. Therefore, our patent related variables are based on annual patent shares. Throughout, we divide the number of firms' patents and citations by the total number of patents and citations of all semiconductor firms in a given year.

\footnotetext{
${ }^{21}$ Further information about the database can be found at http: / / www . nber. org/patents/. One challenge in any study that examines the patenting activities of firms over time is to identify which patents are assigned to individual firms in a given year. Firms may patent under a variety of different firm names over time, see Hall and Ziedonis (2001). This also applies to our licensing data.
} 


\section{B Figures}

Figure 1a

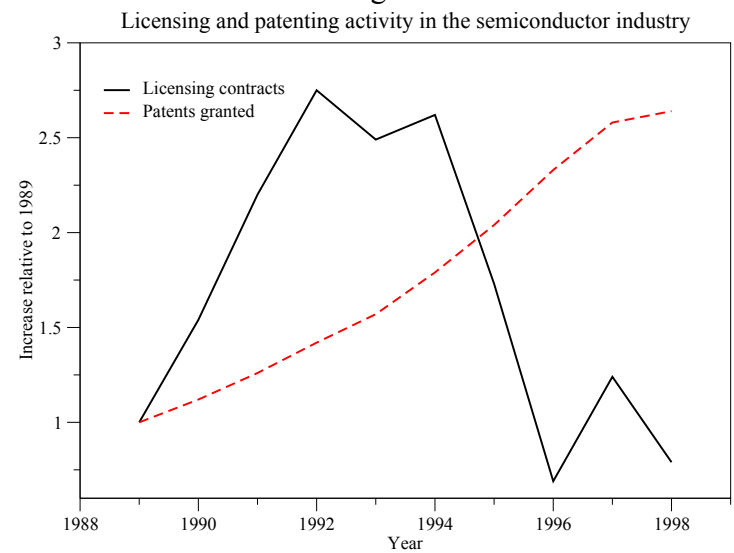

Figure $1 \mathrm{~b}$

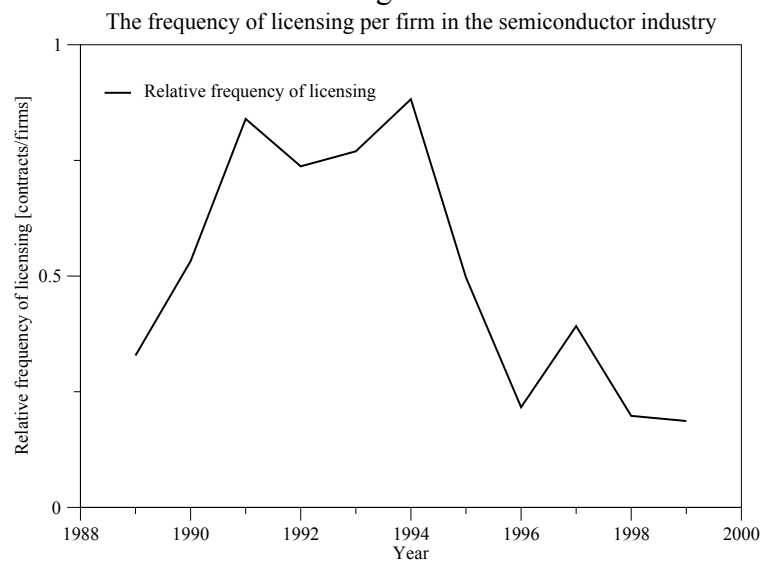

Figures 1a and 1b show the revenues, firms, licensing and patents in the semiconductor industry.

Figure 1c

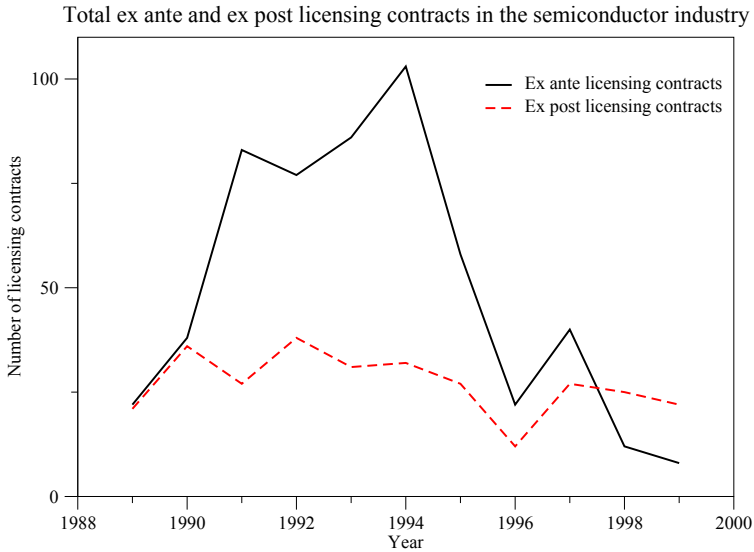

Figure 1d

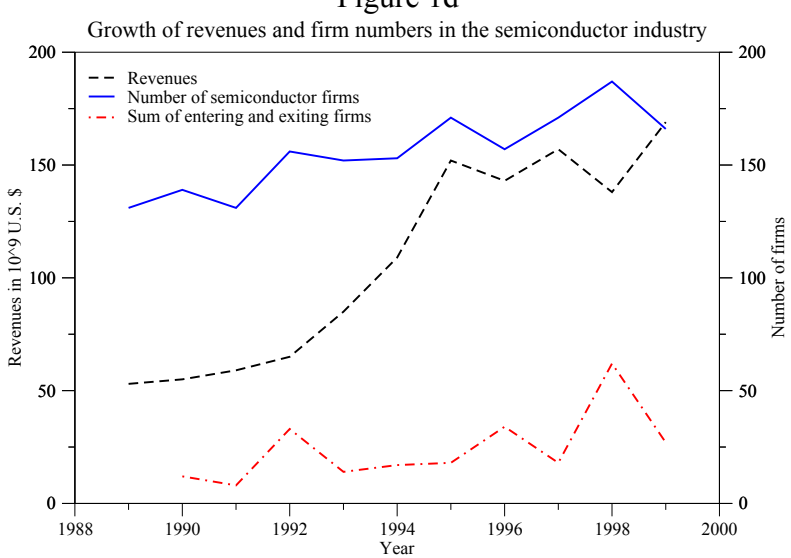

Figures $1 \mathrm{c}$ and $1 \mathrm{~d}$ show the number of ex ante and ex post licensing contracts. 
Figure 2

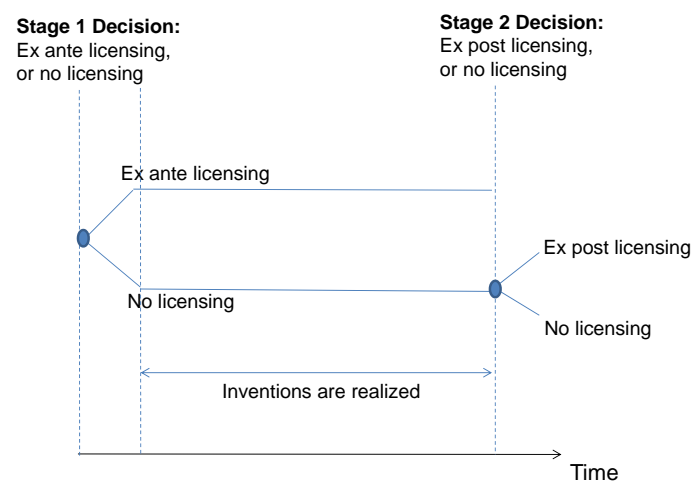

Figure 2 shows the timing of licensing decisions made by firms.
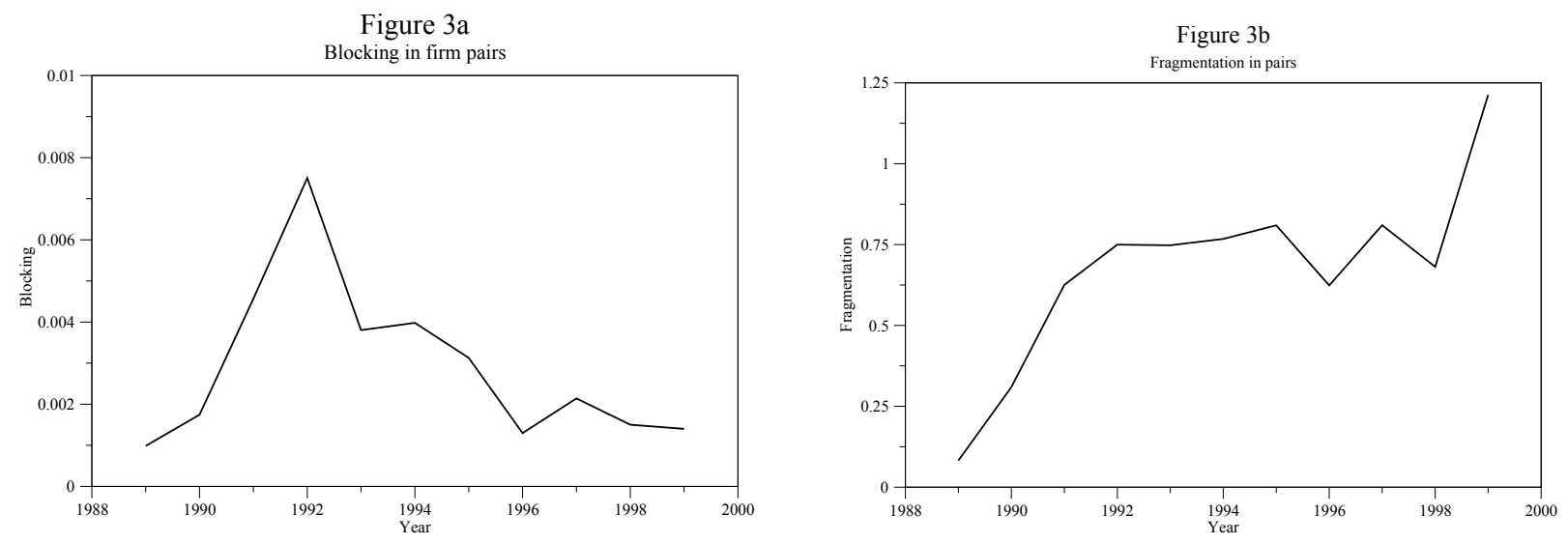

Figures $3 \mathrm{a}$ and $3 \mathrm{~b}$ show the evolution of blocking and fragmentation over time.

\section{Tables}

Table 1: Sample Statistics for Firms by Licensing Contract Type

\begin{tabular}{l|rccc|cccc}
\hline \hline & \multicolumn{4}{|c|}{ Ex post licensing } & \multicolumn{4}{c}{ Ex ante licensing } \\
Variable & Mean & Std. dev. & Min. & Max. & Mean & Std. dev. & Min. & Max. \\
\hline Number of parties & 2.47 & 0.98 & 2 & 6 & 2.39 & 1.16 & 2 & 10 \\
Total contracts & 6.35 & 11.02 & 1 & 44 & 5.57 & 7.25 & 1 & 38 \\
Market shares (\%) & 2.9 & 3.3 & 0 & 16.4 & 2.9 & 2.9 & 0 & 16.4 \\
Patent grants & 128 & 198 & 0 & 873 & 137 & 192 & 0 & 873 \\
Forward citations & 1,056 & 1,341 & 0 & 6,282 & 1,145 & 1,413 & 0 & 6,282 \\
\hline \hline
\end{tabular}

Table 1 provides information on ex ante and ex post licensing agreements. Source: Thomson Financial. 
Table 2: Sample Statistics

\begin{tabular}{|c|c|c|c|c|c|c|c|c|}
\hline \multirow[b]{2}{*}{ Variable } & & \multirow{2}{*}{$\begin{array}{r}\text { Ex ante } \\
\text { licensing } \\
\text { Mean }\end{array}$} & \multirow{2}{*}{$\begin{array}{c}\text { Ex post } \\
\text { licensing } \\
\text { Mean }\end{array}$} & \multirow{2}{*}{$\begin{array}{c}\text { No } \\
\text { licensing } \\
\text { Mean }\end{array}$} & \multicolumn{4}{|c|}{ Full sample } \\
\hline & & & & & Mean & Std. dev. & Min. & Max. \\
\hline Ex ante licensing & $E A L$ & 1 & 0 & 0 & 0.007 & - & 0 & 1 \\
\hline Ex post licensing & $E P L$ & 0 & 1 & 0 & 0.008 & - & 0 & 1 \\
\hline Patents & $A$ & 128.452 & 126.002 & 97.662 & 98.105 & 91.824 & 0 & 790 \\
\hline Expected blocking & $E B$ & 0.007 & 0.009 & 0.004 & 0.004 & 0.009 & 0 & 0.369 \\
\hline Blocking & $B$ & 0.007 & 0.011 & 0.005 & 0.005 & 0.010 & 0 & 0.216 \\
\hline Avg patent stock & $A S P S$ & 530.876 & 474.633 & 371.256 & 373.198 & 424.330 & 0 & 4968.000 \\
\hline Diff patent stocks & $D S P S$ & 632.016 & 542.755 & 483.115 & 484.627 & 570.965 & 0 & 5630.000 \\
\hline Fragmentation & $F$ & 0.818 & 0.874 & 0.672 & 0.675 & 0.844 & 0 & 1.992 \\
\hline Avg market shares & $A S M S$ & 0.030 & 0.030 & 0.024 & 0.024 & 0.019 & 0 & 0.108 \\
\hline Diff market shares & $D S M S$ & 0.030 & 0.027 & 0.030 & 0.030 & 0.026 & 0 & 0.164 \\
\hline Multimarket & $M M K T$ & 1.640 & 1.599 & 1.509 & 1.511 & 0.512 & 1 & 3 \\
\hline Experience EAL & $\operatorname{Exp} E A L$ & 6.702 & 7.925 & 6.090 & 6.110 & 6.896 & 0 & 51 \\
\hline Experience EPL & $\operatorname{ExpEPL}$ & 9.538 & 7.350 & 6.949 & 6.970 & 5.825 & 0 & 37 \\
\hline No. of Observations & & 250 & 294 & 35,731 & & & & \\
\hline
\end{tabular}

Table 2 provides descriptive statistics for the variables used in our regressions. Source: Gartner, Inc. and Thomson Financial. 
Table 3: Estimation Results for Bivariate Probit

\begin{tabular}{|c|c|c|c|c|}
\hline Variable & $\begin{array}{c}E A L \\
(1)\end{array}$ & $\begin{array}{l}E P L \\
(2)\end{array}$ & $\begin{array}{c}E A L \\
(3)\end{array}$ & $\begin{array}{c}E P L \\
(4)\end{array}$ \\
\hline Expected Blocking $(E B)$ & $\begin{array}{l}6.190^{* *} \\
(3.075)\end{array}$ & & $\begin{array}{l}6.131^{* *} \\
(3.064)\end{array}$ & $\begin{array}{c}3.191 \\
(3.132)\end{array}$ \\
\hline Blocking $(B)$ & & $\begin{array}{c}12.65 * * * \\
(2.027)\end{array}$ & & $\begin{array}{c}10.96^{* * * *} \\
(2.554)\end{array}$ \\
\hline$A S P S$ & $\begin{array}{l}-0.164 \mathrm{e}-03 \\
(0.119 \mathrm{e}-03)\end{array}$ & $\begin{array}{l}-0.600 \mathrm{e}-04 \\
(0.981 \mathrm{e}-04)\end{array}$ & $\begin{array}{c}-0.164 \mathrm{e}-03 \\
0.119 \mathrm{e}-03\end{array}$ & $\begin{array}{c}-0.797 e-04 \\
0.999 e-04\end{array}$ \\
\hline$D S P S$ & $\begin{array}{c}0.329 \mathrm{e}-04 \\
(0.647 \mathrm{e}-04)\end{array}$ & $\begin{array}{l}0.107 \mathrm{e}-03^{*} \\
(0.605 \mathrm{e}-04)\end{array}$ & $\begin{array}{c}0.325 \mathrm{e}-04 \\
(0.647 \mathrm{e}-04)\end{array}$ & $\begin{array}{l}0.116 \mathrm{e}-03^{*} \\
(0.613 \mathrm{e}-04)\end{array}$ \\
\hline Fragmentation $(F)$ & $\begin{array}{c}-0.097 * * \\
(0.045)\end{array}$ & $\begin{array}{l}-0.030 \\
(0.037)\end{array}$ & $\begin{array}{c}-0.097 * * \\
(0.045)\end{array}$ & $\begin{array}{l}-0.036 \\
(0.038)\end{array}$ \\
\hline$A S M S$ & $\begin{array}{l}3.426^{*} \\
(1.802)\end{array}$ & $\begin{array}{c}7.688 * * * \\
(1.703)\end{array}$ & $\begin{array}{l}3.428 * \\
(1.802)\end{array}$ & $\begin{array}{c}7.666^{* * * *} \\
(1.710)\end{array}$ \\
\hline$D S M S$ & $\begin{array}{l}-2.378^{*} \\
(1.241)\end{array}$ & $\begin{array}{c}-6.887 * * * \\
(1.327)\end{array}$ & $\begin{array}{l}-2.379^{*} \\
(1.241)\end{array}$ & $\begin{array}{c}-6.889 * * * \\
(1.329)\end{array}$ \\
\hline$M M K T$ & $\begin{array}{c}0.056 \\
(0.060)\end{array}$ & $\begin{array}{l}-0.088 \\
(0.062)\end{array}$ & $\begin{array}{c}0.056 \\
(0.060)\end{array}$ & $\begin{array}{l}-0.086 \\
(0.062)\end{array}$ \\
\hline Experience EAL $(E x p E A L)$ & $\begin{array}{c}0.042 * * * \\
(0.008)\end{array}$ & & $\begin{array}{c}0.042 * * * \\
(0.008)\end{array}$ & \\
\hline Experience EPL $(\operatorname{Exp} E P L)$ & & $\begin{array}{l}0.006^{* *} \\
(0.003)\end{array}$ & & $\begin{array}{l}0.006^{* *} \\
(0.003)\end{array}$ \\
\hline Year Dummies $(D)$ & YES*** & YES*** & YES*** & YES*** \\
\hline Constant & $\begin{array}{c}-2.940 * * * \\
(0.167)\end{array}$ & $\begin{array}{c}-2.484 * * * \\
(0.143)\end{array}$ & $\begin{array}{c}-2.940 * * * \\
(0.167)\end{array}$ & $\begin{array}{c}-2.487 * * * \\
(0.143)\end{array}$ \\
\hline rho & $\begin{array}{c}0.496 * * * \\
(0.054)\end{array}$ & & $\begin{array}{c}0.544 * * * \\
(0.064)\end{array}$ & \\
\hline $\begin{array}{l}-\ln L \\
\text { Number of Observations }\end{array}$ & $\begin{array}{c}2,628.840 \\
30,905\end{array}$ & 30,905 & $\begin{array}{c}2,628.473 \\
30,905\end{array}$ & 30,905 \\
\hline
\end{tabular}

Table 3 reports the estimation results for the bivariate probit model as shown in equations (2) and (3). The bivariate probit model is estimate using a FIML procedure. Robust standard errors are reported in parentheses. ***,**,* refers to a $1 \% 5 \%$, and 10\% significance level. Sources: Thomson Financial, Gartner, Inc. and the U.S. Patent and Trademark Office. 
Table 4: Estimation Results for Bivariate Probit

\begin{tabular}{|c|c|c|c|c|}
\hline Variable & $\begin{array}{r}E A L \\
(1)\end{array}$ & $\begin{array}{r}E P L \\
(2)\end{array}$ & $\begin{array}{r}E A L \\
(3)\end{array}$ & $\begin{array}{r}E P L \\
(4)\end{array}$ \\
\hline Expected Blocking $(E B)$ & $\begin{array}{l}5.482^{*} \\
(3.177)\end{array}$ & & $\begin{array}{l}5.430^{*} \\
(3.168)\end{array}$ & $\begin{array}{r}2.961 \\
(3.148)\end{array}$ \\
\hline Blocking $(B)$ & & $\begin{array}{r}12.247 * * * \\
(2.062)\end{array}$ & & $\begin{array}{r}10.696 * * * \\
(2.575)\end{array}$ \\
\hline Technology $(S)$ & $\begin{array}{r}0.129 \\
(0.097)\end{array}$ & $\begin{array}{r}0.109 \\
(0.086)\end{array}$ & $\begin{array}{r}0.129 \\
(0.097)\end{array}$ & $\begin{array}{r}0.104 \\
(0.086)\end{array}$ \\
\hline$A S P S$ & $\begin{array}{r}-0.163 e-03 \\
(0.119 e-03)\end{array}$ & $\begin{array}{r}-0.641 \mathrm{e}-04 \\
(0.993 \mathrm{e}-04)\end{array}$ & $\begin{array}{r}-0.162 \mathrm{e}-03 \\
(0.119 \mathrm{e}-03)\end{array}$ & $\begin{array}{r}-0.818 \mathrm{e}-04 \\
(1.011 \mathrm{e}-04)\end{array}$ \\
\hline$D S P S$ & $\begin{array}{r}0.345 \mathrm{e}-04 \\
(0.653 \mathrm{e}-04)\end{array}$ & $\begin{array}{l}0.111 \mathrm{e}-03^{*} \\
(0.611 \mathrm{e}-04)\end{array}$ & $\begin{array}{r}0.344 \mathrm{e}-04 \\
(0.653 \mathrm{e}-04)\end{array}$ & $\begin{array}{l}0.119 \mathrm{e}-03 * \\
(0.619 \mathrm{e}-04)\end{array}$ \\
\hline Fragmentation $(F)$ & $\begin{array}{r}-0.122^{* *} \\
(0.050)\end{array}$ & $\begin{array}{r}-0.052 \\
(0.039)\end{array}$ & $\begin{array}{r}-0.121^{* *} \\
(0.050)\end{array}$ & $\begin{array}{r}-0.057 \\
(0.041)\end{array}$ \\
\hline$A S M S$ & $\begin{array}{l}3.372 * \\
(1.807)\end{array}$ & $\begin{array}{r}7.675^{* * *} \\
(1.709)\end{array}$ & $\begin{array}{l}3.373^{*} \\
(1.807)\end{array}$ & $\begin{array}{r}7.656 * * * \\
(1.716)\end{array}$ \\
\hline$D S M S$ & $\begin{array}{l}-2.330^{*} \\
(1.244)\end{array}$ & $\begin{array}{r}-6.887 * * * \\
(1.332)\end{array}$ & $\begin{array}{l}-2.330^{*} \\
(1.244)\end{array}$ & $\begin{array}{r}-6.890 * * * \\
(1.333)\end{array}$ \\
\hline$M M K T$ & $\begin{array}{r}0.056 \\
(0.060)\end{array}$ & $\begin{array}{r}-0.089 \\
(0.062)\end{array}$ & $\begin{array}{r}0.056 \\
(0.060)\end{array}$ & $\begin{array}{l}-0.088 \\
(0.062)\end{array}$ \\
\hline Experience EAL $(\operatorname{Exp} E A L)$ & $\begin{array}{r}0.042^{* * * *} \\
(0.008)\end{array}$ & & $\begin{array}{r}0.042^{* * * *} \\
(0.008)\end{array}$ & \\
\hline Experience EPL $(\operatorname{Exp} E P L)$ & & $\begin{array}{r}0.006^{* *} \\
(0.003)\end{array}$ & & $\begin{array}{r}0.006^{* *} \\
(0.003)\end{array}$ \\
\hline Year Dummies $(D)$ & YES*** & YES*** & YES*** & YES*** \\
\hline Constant & $\begin{array}{r}-2.969^{* * *} \\
(0.168)\end{array}$ & $\begin{array}{r}-2.502 * * * \\
(0.143)\end{array}$ & $\begin{array}{r}-2.969 * * * \\
(0.168)\end{array}$ & $\begin{array}{r}-2.503 * * * \\
(0.144)\end{array}$ \\
\hline rho & $\begin{array}{r}0.501 * * * \\
(0.056)\end{array}$ & & $\begin{array}{r}0.548 * * * \\
(0.066)\end{array}$ & \\
\hline $\begin{array}{l}-\ln L \\
\text { Number of Observations }\end{array}$ & $\begin{array}{r}2,627.33 \\
30,905\end{array}$ & 30,905 & $\begin{array}{r}2,627.021 \\
30,905\end{array}$ & 30,905 \\
\hline
\end{tabular}

Table 4 reports the estimation results for the bivariate probit model as shown in equations (2) and (3) using Technology (T) as an additional control. The bivariate probit model is estimate using a FIML procedure. Robust standard errors are reported in parentheses. $* * *, * *, *$ refers to a $1 \% 5 \%$, and $10 \%$ significance level. Sources:

Thomson Financial, Gartner, Inc. and the U.S. Patent and Trademark Office. 


\section{Empirical Robustness Checks}

As a robustness check for our blocking variable, we establish an alternative blocking variable based on European patent data which uses references to previous patents that block some or all of the subject matter in the patent under consideration are identified. Using this information to measure blocking we exploit the equivalence of U.S. and European patents and run the same bivariate probit selection regression as above.

Table 5: Estimation Results for Bivariate Probit: Robustness Check

\begin{tabular}{|c|c|c|c|c|}
\hline Variable & $\begin{array}{c}E A L \\
(1)\end{array}$ & $\begin{array}{c}E P L \\
(2)\end{array}$ & $\begin{array}{c}E A L \\
\text { (3) }\end{array}$ & $\begin{array}{c}E P L \\
(4)\end{array}$ \\
\hline Expected Blocking $(E B)$ & $\begin{array}{c}0.233^{* * * *} \\
(0.025)\end{array}$ & & $\begin{array}{c}0.232 * * * \\
(0.025)\end{array}$ & $\begin{array}{l}-0.084 \\
(0.153)\end{array}$ \\
\hline Blocking $(B)$ & & $\begin{array}{c}0.149^{* *} \\
(0.065)\end{array}$ & & $\begin{array}{l}0.196^{*} \\
(0.106)\end{array}$ \\
\hline$A S P S$ & $\begin{array}{c}0.799 \mathrm{e}-04 \\
(0.225 \mathrm{e}-03)\end{array}$ & & $\begin{array}{c}0.798 \mathrm{e}-04 \\
(0.227 \mathrm{e}-03)\end{array}$ & \\
\hline$D S P S$ & $\begin{array}{c}0.154 \mathrm{e}-03 \\
(0.129 \mathrm{e}-03)\end{array}$ & $\begin{array}{c}0.185 \mathrm{e}-03 \\
(0.169 \mathrm{e}-03)\end{array}$ & $\begin{array}{c}0.152 \mathrm{e}-03 \\
(0.129 \mathrm{e}-03)\end{array}$ & $\begin{array}{c}0.141 \mathrm{e}-03 \\
(0.211 \mathrm{e}-03)\end{array}$ \\
\hline Fragmentation $(F)$ & $\begin{array}{c}0.033 \\
(0.081)\end{array}$ & $\begin{array}{c}0.043 \\
(0.148)\end{array}$ & $\begin{array}{c}0.033 \\
(0.081)\end{array}$ & $\begin{array}{c}0.055 \\
(0.158)\end{array}$ \\
\hline$A S M S$ & $\begin{array}{l}-4.261 \\
(3.969)\end{array}$ & $\begin{array}{c}12.965 \\
(10.443)\end{array}$ & $\begin{array}{l}-4.427 \\
(3.984)\end{array}$ & $\begin{array}{l}13.625 \\
(0.214)\end{array}$ \\
\hline$D S M S$ & $\begin{array}{c}5.492 * * * \\
(2.189)\end{array}$ & $\begin{array}{c}0.170 \\
(5.183)\end{array}$ & $\begin{array}{c}5.556 * * * \\
(2.196)\end{array}$ & $\begin{array}{c}0.383 \\
(5.378)\end{array}$ \\
\hline$M M K T$ & $\begin{array}{c}0.387 * * * \\
(0.134)\end{array}$ & $\begin{array}{l}-0.675 \\
(0.525)\end{array}$ & $\begin{array}{c}0.387 * * * \\
(0.134)\end{array}$ & $\begin{array}{l}-0.738 \\
(0.564)\end{array}$ \\
\hline Experience EAL $(\operatorname{Exp} E A L)$ & $\begin{array}{l}0.023^{*} \\
(0.013)\end{array}$ & & $\begin{array}{l}0.023 * \\
(0.013)\end{array}$ & \\
\hline Experience EPL $(E x p E P L)$ & $\begin{array}{c}-0.055^{* * *} \\
(0.011)\end{array}$ & & $\begin{array}{c}-0.055^{* * *} \\
(0.011)\end{array}$ & \\
\hline Constant & $\begin{array}{c}-2.815^{* * *} \\
(0.238)\end{array}$ & $\begin{array}{c}-2.215^{* * *} \\
(0.115)\end{array}$ & $\begin{array}{c}-2.810 * * * \\
(0.562)\end{array}$ & $\begin{array}{c}-2.202 * * * \\
(0.587)\end{array}$ \\
\hline rho & $\begin{array}{c}-0.908 * * * \\
(0.102)\end{array}$ & & $\begin{array}{c}-0.879 * * * \\
(0.145)\end{array}$ & \\
\hline $\begin{array}{l}-\ln L \\
\text { Number of Observations }\end{array}$ & $\begin{array}{c}373.349 \\
2,745\end{array}$ & 2,745 & $\begin{array}{c}373.169 \\
2,745\end{array}$ & 2,745 \\
\hline
\end{tabular}

Table 5 reports the estimation results for our robustness check on the blocking variable. The results are similar to those presented in Table 3 and confirm our earlier findings. Thębivariate probit model is estimate using a FIML procedure. 


\section{References}

Albert, M., D. Avery, F. Narin, and P. McAllister (1991). Direct validation of citation counts as indicators of industrially important patents. Research Policy 20, pp. 250-259.

Anand, B. and T. Khanna (2000). The structure of licensing contracts. The Journal of Industrial Economics 48, 103-135.

Arora, A. and M. Ceccagnoli (2006). Patent protection, complementary assets, and firms incentives for technology licensing. Management Science 52, 293-308.

Arora, A. and A. Fosfuri (2003). Licensing the market for technology. Journal of Economic Behavior and Organization 52, 277-295.

Bloom, N., M. Schankerman, and J. V. Reenen (2013). Identifying technology spillovers and product market rivalry. Econometrica forthcoming.

Branstetter, L. and M. Sakakibara (2002). When do research consortia work well and why? evidence from japanese panel data. American Economic Review 92(1), 143.

Clark, D. J. and K. A. Konrad (2008). Fragmented property rights and incentives for R\&D. Management Science 54(5), pp. 969-981.

D’Aspremont, C. and A. Jacquemin (1988). Cooperative and noncooperative r\&d in duopoly with spillovers. American Economic Review 78, 1133.

Duso, T., L.-H. Roeller, and J. Seldeslachts (2013). Collusion through joint r\&d: An empirical assessment. American Economic Review forthcoming.

Epstein, R., F. Kieff, and D. Spulber (2012). The ftc, ip, and ssos: Government hold-up replacing private coordination. Journal of Competition Law and Economics, 146. 
Federal Trade Commission (2003). To promote innovation - the proper balance of competition and patent law and policy. Report, GPO.

Galasso, A. (2012). Broad cross-license negotiations. Journal of Economics and Management Strategy 21, 873-911.

Galasso, A. and M. Schankerman (2010). Patent thickets, courts, and the market for innovation. Rand Journal of Economics 41(3), 472.

Galasso, A., M. Schankerman, and C. Serrano (2013). Trading and enforcing patent rights. RAND Journal of Economics 44, 275.

Gallini, N. (1984). Deterrence by market sharing: A strategic incentive for licensing. American Economic Review 74(1), 931.

Gallini, N. (2011). Private agreements for coordinating patent rights: the case of patent pools. ECONOMIA E POLITICA INDUSTRIALE 3, 5.

Gallini, N. and R. Winter (1985). Licensing in the theory of innovation. RAND Journal of Economics 16, 237.

Gans, J., D. Hsu, and S. Stern (2008). The impact of uncertain intellectual property rights on the market for ideas: Evidence from patent grant delays. Management Science 54, 982.

Gilbert, R. and M. Katz (2011). Efficient division of profits from complementary innovations. International Journal of Industrial Organization 29(4), 443.

Goeree, M. and E. Helland (2012). Do research joint ventures serve a collusive function? Working Papers.

Green, J. R. and S. Scotchmer (1995). On the division of profit in sequential innovation. Rand Journal of Economics 25(1), 20-33. 
Greenlee, P. (2005). Endogenous formation of competitive research sharing joint ventures. The Journal of Industrial Economics 53, 355.

Grindley, P. C. and D. J. Teece (1997). Managing intellectual capital: Licensing and cross-licensing in semiconductors and electronics. California Management Review 39(2), pp. 8-41.

Hall, B. H., A. Jaffee, and M. Trajtenberg (2005). Market value and patent citations. Rand Journal of Economics 36, pp.16-38.

Hall, B. H. and R. Ziedonis (2001). The patent paradox revisited: An empirical study of patenting in the U.S. semiconductor industry, 1979-1995. Rand Journal of Economics 32(1), pp. 101-128.

Heckman, J. (1979). Sample selection bias as a specification error. Econometrica 47(1), 153.

Heller, M. A. and R. S. Eisenberg (1998). Can patents deter innovation? The anticommons in biomedical research. Science 280, pp. 698-701.

Jaffe, A. B. (1986). Technological opportunity and spillovers of R\&D: Evidence from firms' patents, profits and market value. American Economic Review 76, pp. 984-1001.

Jeitschko, T. and N. Zhang (2013). Deterrence by market sharing: A strategic incentive for licensing. DICE working paper.

Kamien, M., E. Muller, and I. Zang (1992). Deterrence by market sharing: A strategic incentive for licensing. American Economic Review 82, 1293.

Katz, M. (1986). An analysis of cooperative research and development. RAND Journal of Economics 17(4), 527.

Katz, M. and C. Shapiro (1987). R\&d rivalry with licensing or imitation. American Economic Review 77, 402.

Lampe, R. and P. Moser (2010). Do patent pools encourage innovation? evidence from the 19thcentury sewing machine industry. Journal of Economic History 70, 898. 
Lampe, R. and P. Moser (2012). Do patent pools encourage innovation? evidence from 20 u.s. industries under the new deal. working paper.

Lei, Z. and B. Wright (2009). Why weak patents? Rational ignorance or pro-'customer'tilt? University of California, Berkeley.

Lerner, J. (1995). Patenting in the shadow of competitors. Journal of Law and Economics 38, 463-95.

Lerner, J. and J. Tirole (2004). Efficient patent pools. American Economic Review 94(3), 691 711.

Levin, R. C., A. K. Klevorick, R. R. Nelson, and S. G. Winter (1987). Appropriating the returns from industrial research and development. Brookings Papers on Economic Activity 3(783-820).

Maddala, G. (1986). Limited-dependent and qualitative variables in econometrics.

Merges, R. and R. Nelson (1990). On the complex economics of patent scope. Columbia Law Review 90(4).

Merges, R. P. (2001). Institutions for intellectual property transactions: The case of patent pools. In R. Dreyfuss, D. Zimmermann, and H. First (Eds.), Expanding for the Knowledge Society, pp. 123-166. Oxford: Oxford University Press.

Noel, M. and M. Schankerman (2013). Strategic patenting and software innovation. Journal of Industrial Economics 61, 481.

Nordhaus, W. (1969). Invention, Growth and Welfare: A Theoretical Treatment of Technological Change. Cambridge, Mass.: MIT Press.

Roeller, L., R. Siebert, and M. Tombak (2007). Why firms form (or don't form) rjvs. Economic Journal 117(522), 1122.

Scotchmer, S. (2005). Innovation and Incentives. Cambridge, Mass.: MIT Press. 
Shapiro, C. (1982). Optimal patents with compulsory licensing. Journal of Political Economy 90, 470.

Shapiro, C. (2001). Navigating the patent thicket: Cross licenses, patent pools, and standardsetting. In A. B. Jaffe, J. Lerner, and S. Stern (Eds.), Innovation Policy and the Economy, Volume 1, pp. 119-150. Cambridge, Mass.: MIT Press.

Spulber, D. (2012). Competing inventors and the incentive to invent. Industrial and Corporate Change.

Stuart, T. (1998). Network positions and propensities to collaborate: An investigation of strategic alliance formation in a high- technology industry. Administrative Science Quarterly 43, pp. $668-698$.

Teece, D. (1986). Profiting from technological innovation: Implications for integration, collaboration, licensing and public policy. Research Policy 15, 285-305.

Tirole, J. (1988). The Theory of Industrial Organization. Cambridge, Mass.: MIT Press.

Wooldridge, J. M. (2002). Econometric analysis of cross section and panel data. Cambridge, Mass.: MIT Press.

Ziedonis, R. H. (2004). Don't fence me in: Fragmented markets for technology and the patent acquisition strategies of firms. Management Science 50(6), pp. 804-820. 